\title{
Augmented Reality Book Pengenalan Tata Letak Bangunan Pura Pulaki dan Pura Melanting
}

\author{
Putu Yoka Angga Prawira ${ }^{1}$, Padma Nyoman Crisnapati ${ }^{2}$, \\ I Made Gede Sunarya ${ }^{3}$, I Gede Mahendra Darmawiguna ${ }^{4}$ \\ Jurusan Pendidikan Teknik Informatika \\ Universitas Pendidikan Ganesha \\ Singaraja, Bali \\ E-mail:yokaangga@ rocketmail.coml, crisnapati@yahoo.com ${ }^{2}$,imadegedesunarya@gmail.com², \\ igd.mahendra.d@gmail.com ${ }^{4}$
}

\begin{abstract}
Abstrak- Pura Pulaki berdiri di atas tebing berbatu yang langsung menghadap ke laut. Di latar belakangnya terbentang bukit terjal yang berbatu yang hanya sekali-sekali saja tampak hijau saat musim hujan. Pura ini tampak berwibawa, teguh dan agung, justru karena berdiri di tempat yang teramat sulit. Apalagi pemandangan yang ditampilkan begitu menawan. Jika berdiri di dalam pura lalu memandang ke depan, bukan hanya laut yang bakal tampak namun juga segugus bukit kecil di sebelah baratnya yang berbentuk tanjung. Kera-kera yang hidup di sekitar pura ini, meski terkesan galak, juga menciptakan daya tarik tersendiri.

Metode penelitian yang digunakan adalah penelitian dan pengembangan, untuk mengembangkan aplikasi Augmented Reality Book pengenalan tata letak Pura Pulaki dan Pura Melanting, dengan menggunakan model waterfall sampai pada tahap pengujian sistem. Aplikasi ini menggunakan library vuforia yang mampu menampilkan objek 3 dimensi bangunan ke dalam sebuah lingkungan nyata dengan menggunakan bantuan buku dan smartphone android.

Hasil akhirnya berupa buku yang berisikan informasi dan gambar terkait Pura Pulaki dan Pura Melanting yang difungsikan sebagai penanda dan juga aplikasi Augmented Reality Book berbasis android yang mampu menampilkan objek bangunan Pura Pulaki dan Pura Melanting dalam bentuk 3 dimensi tepat di atas marker lengkap dengan suara narasi penjelasan. Aplikasi ini dapat dijadikan sebagai media untuk memperkenalkan sekaligus melestarikan budaya bangsa.
\end{abstract}

Kata kunci : $\quad$ Pura Pulaki, Pura Melanting, Augmented Reality Book, library Vuforia.

Abstract- Pulaki Temple has stand on rocky cliff wich facing the sea. At background have a rocky steep hill, when sometimes look green on rainy season.
This temple looks authoritative, firm and great, because of this temple stand on hard place. Moreover this temple have a great view. If stand in the temple and look straight the sea, not only sea you will see but you can see some little hill on the western side. There is many monkeys live around the temple, although look like fierce, this monkeys presenting an attraction.

This research includes research and development methods. In developing these applications using the waterfall model to the system testing phase. This application uses libraries vuforia capable of displaying three-dimensional objects into a temple building a real environment with the help of books and Android smartphones. Mechanical testing of these applications is done by giving questionnaires to the respondents. Questionnaire was used to test the spesific object with marker, test how long the objects showing in outside and indoors, and test the suitability of applications on several different Android smartphones.

The results of this research in the form of a book containing information and images markers (markers) associated Pura Pulaki dan Pura Melanting well as Augmented Reality Book-based application that is capable of displaying android Pura Pulaki and Melanting building objects in the form of 3 dimensional image just above the marker (marker) complete with sound narrative explanations in English. This application can be used as a medium to maintain, introduce, at the same time preserving the nation's cultural assets.

Keyword: $\quad$ Pulaki Temple, Melanting Temple, Augmented Reality Book, library Vuforia.

\section{PENDAHULUAN}

Indonesia dikenal kaya akan seni dan budayanya. Setiap daerah dari ujung timur 
Indonesia sampai dengan ujung barat Indonesia memiliki seni dan budaya yang berbeda-beda yang merupakan warisan budaya yang terus berkembang berabad-abad. Provinsi Bali adalah salah satu pulau tujuan wisata, pulau yang dikenal dengan nama pulau Dewata yang sudah sangat terkenal di dunia dengan beragam seni dan budaya baik itu seni musik tradisional Bali yang menggunakan tabuh gamelan, seni tari yang memiliki beragam jenis tarian yang memiliki keunikan dalam setiap gerakanya, kebudayaan berpakaian adat masyarakat Bali, upacara adat yang ada di Bali dan tidak lupa pura-pura yang ada di Bali.

Salah satu pulau di Indonesia yang sangat kaya akan warisan dan potensi kebudayaannya adalah pulau Bali. Membahas mengenai warisan dan potensi kebudayaan Bali memang tidak akan ada habisnya. "Kebudayaan Bali merupakan kebudayaan yang didukung oleh etnik Bali yang beragama Hindu sebagai bagian dari kebudayaan Indonesia yang bersifat Bhineka Tunggal Ika" [1].

Salah satu warisan kebudayaan yang menjadi kebanggaan orang Bali adalah arsitektur tradisional yang sampai saat ini masih tetap hidup dan terus mengalami perkembangan.

Arsitektur tradisional adalah perwujudan ruang untuk menampung aktivitas kehidupan manusia dengan pengulangan bentuk dari generasi ke generasi berikutnya dengan sedikit atau tanpa perubahan, yang dilatar belakangi oleh normanorma agama dan dilandasi oleh adat kebiasaan setempat serta dijiwai kondisi dan potensi alam lingkungannya [2].

Pura Pulaki berdiri di atas tebing berbatu yang langsung menghadap ke laut. Di latar belakangnya terbentang bukit terjal yang berbatu yang hanya sekali-sekali saja tampak hijau saat musim hujan. Pura ini tampak berwibawa, teguh dan agung, justru karena berdiri di tempat yang teramat sulit. Apalagi pemandangan yang ditampilkan begitu menawan. Jika berdiri di dalam pura lalu memandang ke depan, bukan hanya laut yang bakal tampak namun juga segugus bukit kecil di sebelah baratnya yang berbentuk tanjung. Kera-kera yang hidup di sekitar pura ini, meski terkesan galak, juga menciptakan daya tarik tersendiri.

Sayangnya, Pura Pulaki ini tidak begitu terkenal jika dibandingkan dengan pura-pura yang berada di objek wisata lainnya, selain jarak tempuh yang cukup jauh dari pusat kota, Pura Pulaki dan Pura Melanting juga kurang mendapat promosi sebagai objek wisata di kancah dunia. Demi melestarikan budaya dan mengenalkan Pura Pulaki dan Pura Melanting di mata dunia dapat dilakukan dengan berbagai cara, salah satunya dapat diupayakan dengan bantuan teknologi.

Kelebihan multimedia adalah menarik indera dan minat, karena merupakan gabungan antara pandangan, suara dan gerakan. Lembaga Riset dan Penerbitan Komputer yaitu Computer Technology Research (CTR), menyatakan bahwa orang hanya mampu mengingat $20 \%$ dari yang dilihat dan $30 \%$ dari yang didengar. Tetapi orang dapat mengingat $50 \%$ dari yang dilihat dan didengar dan $30 \%$ dari yang dilihat, didengar dan dilakukan sekaligus, maka multimedia sangatlah efektif. Multimedia menjadi tool yang ampuh untuk pengajaran dan pendidikan serta untuk meraih keunggulan bersaing perusahaan [3].

Berdasarkan paparan tersebut, peneliti termotivasi mengembangkan sebuah aplikasi Augmented Reality Book yang menampilkan animasi 3 dimensi tentang Pura Pulaki dan Pura Melanting dalam bentuk penelitian yang berjudul. "Pengembangan Aplikasi Augmented Reality Book Pengenalan Tata Letak Bangunan Pura Pulaki dan Pura Melanting".

\section{A. Augmented Reality}

\section{KAJIAN TEORI}

Secara umum, Augmented Reality (AR) adalah suatu teknologi yang menggabungkan benda maya dua dimensi dan ataupun tiga dimensi ke dalam sebuah lingkungan nyata tiga dimensi lalu memproyeksikan benda-benda maya tersebut dalam waktu nyata. Tidak seperti realitas maya yang sepenuhnya menggantikan kenyataan, namun Augmented Reality hanya menambahkan atau melengkapi kenyataan.

Augmented Reality (AR) adalah teknologi yang menggabungkan benda maya dua dimensi dan ataupun tiga dimensi ke dalam sebuah lingkungan nyata lalu memproyeksikan bendabenda maya tersebut dalam waktu nyata. Bendabenda maya berfungsi menampilkan informasi yang tidak dapat diterima oleh manusia secara langsung [4].

\section{B. Vuforia}

Vuforia merupakan software library untuk Augmented Reality, yang menggunakan sumber yang konsisten mengenai computer vision yang fokus pada image recognition. Vuforia mempunyai banyak fitur-fitur dan kemampuan, yang dapat membantu pengembang untuk mewujudkan pemikiran mereka tanpa adanya batas secara teknikal. Dengan support untuk iOS, Android, dan 
Unity3D, platform Vuforia mendukung para pengembang untuk membuat aplikasi yang dapat digunakan dihampir seluruh jenis smartphone dan tablet.

Pengembang juga diberikan kebebasan untuk mendesain dan membuat aplikasi yang mempunyai kemampuan antara lain :

1. Teknologi computer vision tingkat tinggi.

2. Terus-menerus mengenali multiple image.

3. Tracking dan Detection tingkat lanjut.

4. Dan solusi pengaturan database gambar yang fleksibel.

\section{Augmented Reality Book}

Augmented Reality Book (AR-Book) atau yang dalam bahasa Indonesia berarti buku berbasis augmented reality merupakan penggabungan antara buku biasa dengan teknologi AR. AR-Book secara garis besar memiliki dua komponen utama, yaitu buku yang dilengkapi dengan marker berjenis Quick Response Code (QRC) pada hampir setiap halamannya, dan yang kedua yaitu peralatan untuk menangkap marker dan menampilkan hasilnya. Alat tersebut dapat berbentuk handheld display (HHD), head mounted display (HMD), virtual retinal display (VRD), atau bahkan tampilan berbasis layar biasa.

\section{Pura Pulaki}

Pura Pulaki berdiri di atas tebing berbatu yang langsung menghadap ke laut. Di latar belakangnya terbentang bukit terjal yang berbatu yang hanya sekali-sekali saja tampak hijau saat musim hujan. Pura ini tampak berwibawa, teguh dan agung, justru karena berdiri di tempat yang teramat sulit. Apalagi pemandangan yang ditampilkan begitu menawan. Jika berdiri di dalam pura lalu memandang ke depan, bukan hanya laut yang bakal tampak namun juga segugus bukit kecil di sebelah baratnya yang berbentuk tanjung. Kera-kera yang hidup di sekitar pura ini, meski terkesan galak, juga menciptakan daya tarik tersendiri.

Pura Pulaki terletak di Desa Banyupoh Kecamatan Gerokgak, Buleleng, sekitar 53 kilometer di sebelah barat kota Singaraja. Pura ini terletak di pinggir jalan raya jurusan SingarajaGilimanuk, sehingga umat Hindu akan selalu singgah untuk bersembahyang jika kebetulan lewat dari Gilimanuk ke Singaraja atau seBaliknya. Namun jika ingin bersembahyang secara beramairamai, umat bisa datang saat digelar rangkaian piodalan yang dimulai pada Purnama Sasih Kapat. Sejarah Pura Pulaki memang tak bisa dijelaskan secara tepat. Namun, dari berbagai potongan data yang tertinggal, sejarah pura itu setidaknya bisa dirunut dari zaman prasejarah.

\section{E. Pura Melanting}

Pura Melanting terletak di Desa Banyupoh Kecamatan Gerokgak, Buleleng, sekitar 52 kilometer di sebelah barat kota Singaraja. Pura ini terletak di pinggir jalan raya jurusan SingarajaGilimanuk. Pura Melanting terletak cukup dekat dengan Pura Pulaki sekitar 1 kilometer.

\section{ANALISIS DAN PERANCANGAN}

\section{A. Analisis Masalah dan Solusi}

Pengembangan aplikasi Augmented Reality Book pengenalan tata letak Pura Pulaki dan Pura Melanting ini mengunakan proses SDLC (System Development Life Cycle) dengan model waterfall yaitu model yang bersifat sistematis dan berurutan dalam membangun perangkat lunak, mulai dari tahap analisis, desain, implementasi, testing, operation, dan maintenance.Dimana tahap pertama yang dilakukan adalah analisis masalah dan solusi yang merupakan bagian dari Requirements analysis and definition (analisis kebutuhan dan definisi) pada model tersebut.

Pada tahap analisis masalah, penulis melakukan penelitian dan pencarian informasi terkait bangunan Pura Pulaki dan Pura Melanting. Seperti yang telah diketahui, Pura Pulaki yang berada di kawasan Pulaki desa Banyu Poh Kecamatan Gerokgak dikenal sebagai tempat wisata monyet yang berada di kabupaten Buleleng Bali. Pura Pulaki dengan luas sekitar $5 \mathrm{Ha}$ ditempati oleh fauna monyet ekor panjang dan merupakan cagar alam untuk melindungi dan melestarikan hutan. Menurut survei yang dilakukan oleh Wandia kawasan ini dihuni oleh \pm 68 ekor monyet ekor panjang. Satwa primata ini perlu dipertahankan keberadaannya karena telah berkontribusi besar terhadap perkembangan ekonomi masyarakat sekitar [5].

Menurut BMKG Indonesia merupakan daerah rawan gempabumi karena dilalui oleh jalur pertemuan 3 lempeng tektonik, yaitu: Lempeng Indo-Australia, lempeng Eurasia, dan lempeng Pasifik.Lempeng Indo-Australia bergerak relatip ke arah utara dan menyusup kedalam lempeng Eurasia, sementara lempeng Pasifik bergerak relatip ke arah barat.Jalur pertemuan lempeng berada di laut sehingga apabila terjadi gempabumi besar dengan kedalaman dangkal maka akan berpotensi menimbulkan tsunami sehingga 
Indonesia juga rawan tsunami. Dikarenakan Pura Pulaki terletak di pinggir pantai maka tidak mustahil jika suatu saat Pura Pulaki dan Pura Melanting hilang disebabkan oleh gempa bumi dan tsunami. Maka dari itu pura pulaki dapat diabadikan dalam suatu animasi 3 dimensi yang salah satunya Augmented Reality.

Berdasarkan analisis masalah di atas maka dapat diusulkan solusi berupa pemanfaatan teknologi untuk ikut serta melestarikan kebudayaan Indonesia, khususnya Bali, yaitu sebuah perangkat lunak (aplikasi) augmented reality yang dapat digunakan untuk membantu melestarikan kebudayaan Bali, yang dalam hal ini adalah bangunan Pura Pulaki dan Pura Melanting. Dengan bantuan Augmented Reality masyarakat juga dapat mempelajari seperti apa bangunan yang ada di Pura Pulaki dan Pura Melanting tanpa harus berada langsung di area Pura Pulaki dan Pura Melanting. Augmented Reality bisa menjadi media pembelajaran sekaligus media informasi yang menarik secara visual.

Aplikasi ini berupa aplikasi yang dapat menampilkan objek 3 dimensi berupa bangunan Pura Puaki dan Pura Melanting beserta tata letaknya. Selain pengembangan aplikasi, juga dibuat referensi berupa buku yang berisikan informasi mengenai bangunan pura dan peta terkait bangunan Pura Pulaki dan Pura Melanting yang digunakan sebagai penanda agar dapat menampilkan objek 3 dimensi. Diharapkan dengan dikembangkannya aplikasi ini mampu melestarikan sekaligus menambah kepedulian kita terhadap kebudayaan yang kita miliki.

\section{B. Perancangan Sistem dan Perangkat Lunak}

Proses perancangan sistem dan perangkat lunak adalah proses pembentukan system yang akan di buat nantinya.

Ketika tahap pengumpulan teori dan mendefinisikan kebutuhan sudah lengkap, maka dilanjutkan dengan membuat rancangan dari aplikasi yang akan dibuat. Pada tahap ini dilakukan proses perancangan aplikasi dan perancangan Book Design untuk buku dengan teknologi Augmented Reality ini.

\section{Rancangan Aplikasi}

Rancangan ini dimaksudkan untuk dapat menciptakan sistem yang mudah digunakan dan dimengerti oleh user. Rancangan aplikasi (Flowchart) untuk aplikasi ini adalah seperti pada gambar 1 .

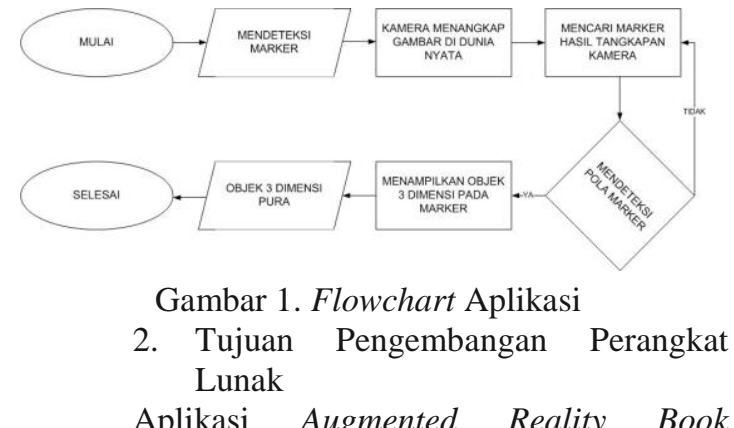
pengenalan tata letak bangunan Pura Pulaki dan Pura Melanting merupakan perangkat lunak yang digunakan untuk menampilkan objek 3 dimensi berupa bangunan Pura beserta tata letaknya, tepat diatas gambar penanda ketika diarahkan oleh kamera smartphone. Aplikasi ini diharapkan mampu memenuhi proses-proses sebagai berikut:

a. Mampu menampilkan bangunan Pura Pulaki dan Pura Melanting dalam bentuk 3D.

b. Mampu menampilkan tata letak bangunan pura yang muncul lengkap dengan narasi penjelasannya.

\section{Masukan dan Keluaran Perangkat Lunak}

Pada perangkat lunak Augmented Reality Book pengenalan tata letak bangunan Pura Pulaki dan Pura Melanting ini terdapat data masukan dan keluaran sebagai berikut.

\section{a. Masukan Perangkat Lunak}

Masukan dalam perangkat lunak Augmented Reality Book pengenalan tata letak bangunan Pura Pulaki dan Pura Melanting adalah marker atau penanda yang ditampilkan pada buku dan gambar atau frame hasil tangkapan kamera ketika mencari marker.

\section{b. Keluaran Perangkat Lunak}

Keluaran dari perangkat lunak ini adalah objek 3 dimensi bangunan pura beserta tata letaknya yang dihasilkan dari hasil pencocokan marker lengkap dengan narasi penjelasannya.

\section{Model Fungsional Perangkat Lunak}

Pada model fungsional perangkat lunak menjelaskan gambaran umum dari perangkat lunak. Gambar 2 menjelaskan alur dari pembuatan perangkat lunak. Mulai dari pembuatan objek 3 dimensi, pembuatan file suara, pencarian dan pembentukan gambar sehingga menjadi library marker, digabungkan menjadi satu projek 
augmented reality ditambah library $\mathrm{AR}$ (augmented reality) dan proses coding yang merupakan komponen utama pengembangan perangkat lunak augmented reality. Menghasilkan aplikasi AR untuk android yang dapat digunakan langsung pada buku yang sudah dilengkapi marker, sehingga menghasilkan output berupa objek 3 dimensi dan suara. Suara yang dihasilkan bisa disesuakin pada waktu perekaman dan masukan suara akan keluar pada saat apalikasi menangkap marker yang terdapat pada frame atau gambar, narasi atau suara yang keluar sesuai dengan gambar atau setiap gambar memiliki narasi atau suara yang berbeda-beda.

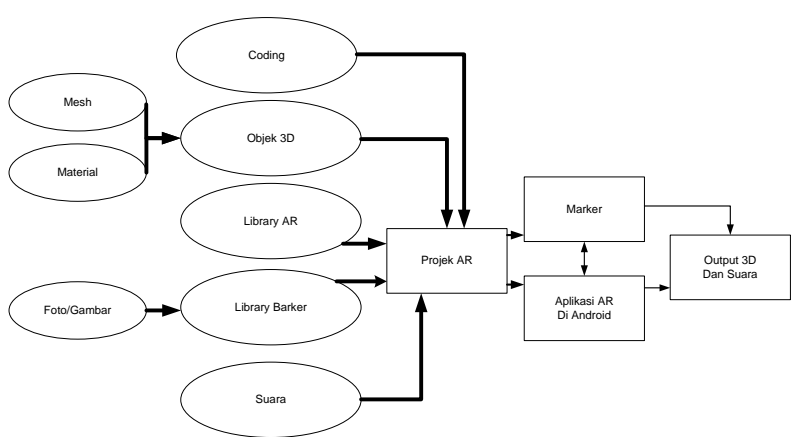

Gambar 2. Alur Pembuatan Perangkat Lunak

Rancangan aplikasi (Flowchart) untuk aplikasi Augmented Reality Book pengenalan tata letak Pura Pulaki dan Pura Melanting dibuat sesuai dengan pengamatan peneliti, rancangan aplikasi (flowchart) dapat dilihat pada Gambar 3.

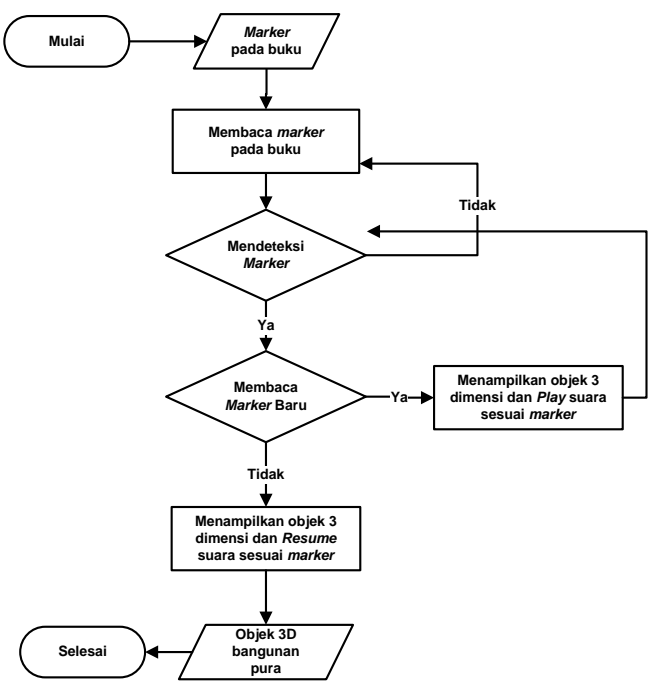

Gambar 3. Flowchart Rancangan AR Book

Gambaran umum interaksi yang terjadi antara user dengan aplikasi augmented reality bangunan Pura Pulaki dan Pura Melanting dapat dilihat pada
Gambar 4, dimana user akan berinteraksi langsung dengan smartphone android yang sudah dilengkapi dengan aplikasi augmented reality. Ketika kamera dari smartphone diarahkan ke buku Pulaki dan Pura Melanting yang sudah dilengkapi gambar penanda/marker maka akan muncul objek 3 dimensi bangunan pura beserta suara narasi yang sesuai dengan marker pada layar smartphone, yang merupakan output aplikasi yang dapat dinikmati oleh user.

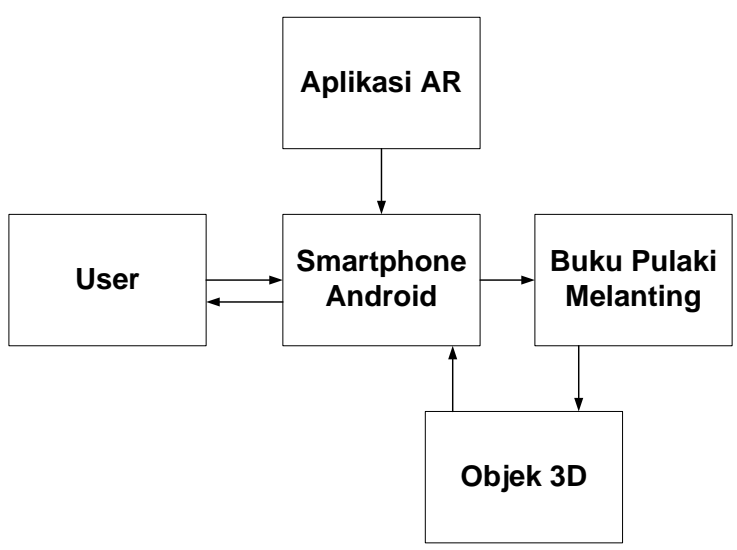

Gambar 4. Proses Interaksi Perangkat Lunak Dengan User

C. Perancangan Perangkat Lunak

Tahap perancangan perangkat lunak adalah tahap selanjutnya setelah melakukan analisis perangkat lunak. Rancangan perangkat lunak yang dibuat bersifat user friendly agar pengguna merasa nyaman dan mudah untuk menggunakannya. Adapun bagian - bagian dari tahap ini dapat dipaparkan sebagai berikut.

\section{Batasan Perancangan Perangkat Lunak}

Aplikasi ini hanya dapat berjalan pada perangkat android versi 4.0 (IceCreamSandwich) keatas,dengan OpenGL ES diatas 2.0, dan arsitektur ARMv7.

2. Perancangan Arsitektur Perangkat Lunak

Perancangan arsitektur perangkat lunak menggambarkan bagian-bagian modul, struktur ketergantungan antar modul, dan hubungan antar modul dari perangkat lunak yang dibangun.

Structure chart sebagai kendali fungsional yang digambarkan seperti Gambar 10 untuk perangkat lunak Augmented Reality Book 
pengenalan tata letak bangunan Pura Pulaki dan Pura Melanting

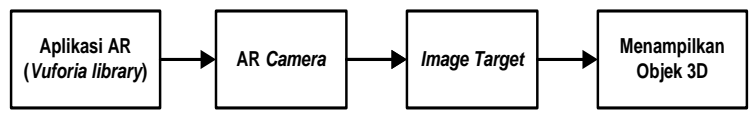

Gambar 5. Structure Chart

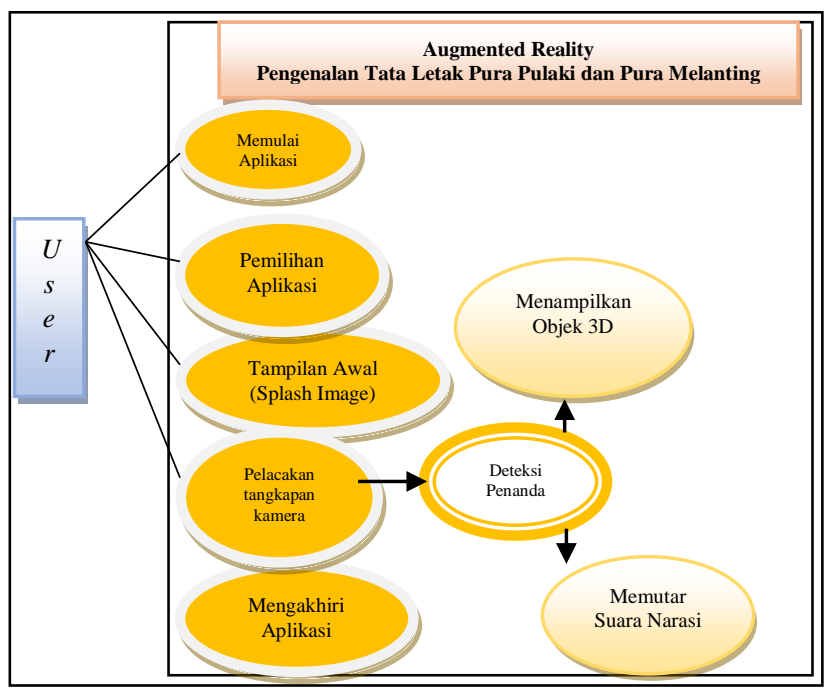

Gambar 6. Use Case Diagram

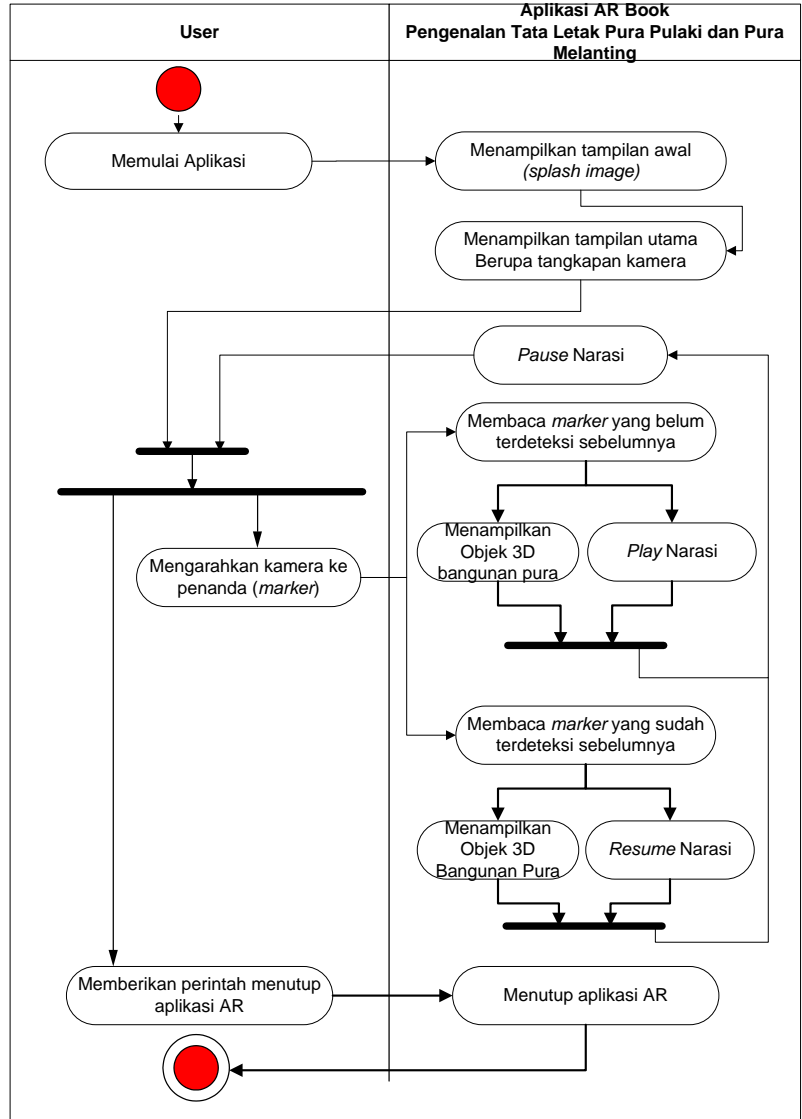

Gambar 7. Activity Diagram

\section{IMPLEMENTASI PERANGKAT LUNAK}

A. Implementasi Perangkat Lunak

Implementasi perangkat lunak Augmented Reality Book pengenalan Tata Letak Bangunan Pura Pulaki dan Pura Melanting di Kabupaten Buleleng ini terdiri dari lingkungan implementasi perangkat lunak, batasan implementasi perangkat lunak, implementasi arsitektur perangkat lunak, implementasi struktur data perangkat lunak serta implementasi layar antarmuka perangkat lunak.

1. Lingkungan Implementasi Perangkat Lunak

Pada lingkungan perangkat lunak, aplikasi Augmented Reality Book pengenalan tata letak bangunan Pura Pulaki dan Pura Melanting dijalankan pada lingkungan sebagai berikut.

1. Sistem Operasi Microsoft Windows 7 Ultimate.

2. Sistem Operasi Android Jelly Bean v4.1.2.

3. Blender 2.68. 
4. Vuforia Qualcomm Augmented Reality.

5. Unity4.2.0f4.

6. SDK Android Tools.

Komputer :

1. Laptop Asus N46VM.

2. Intel®Core ${ }^{\mathrm{TM}}$ i7 CPU @ $2.30 \mathrm{GHz}$.

3. VGA NVIDIA GEFORCE GT 630M $2 \mathrm{~GB}$.

4. RAM 4.00 GB.

5. Harddisk $750 \mathrm{~GB}$.

6. Dilengkapi alat input dan output.

2. Batasan Implementasi Perangkat Lunak

Batasan yang terdapat dalam implementasi perangkat lunak aplikasi Augmented Reality Book pengenalan tata letak bangunan Pura Pulaki dan Pura Melanting yaitu aplikasi ini hanya dapat berjalan pada perangkat android versi 4.0 (IceCreamSandwich) keatas, dengan OpenGL ES diatas 2.0, dan arsitektur ARMv7.

\section{Implementasi Arsitektur Perangkat Lunak}

Sesuai dengan hasil perancangan arsitektur perangkat lunak, dapat diimplementasikan proses yang digunakan untuk membuat Perangkat lunak Augmented Reality Book Pengenalan Tata Letak Bangunan Pura Pulaki dan Pura Melanting, yakni

\section{ExitProgram.cs,}

DefaultTrackableEventHandler.cs,

DataSetLoadBehaviour.cs, QCARBehaviour.cs, dan ImageTargetBehaviour.cs. Penerapan pada perangkat lunak Unity menggunakan class - class yang disimpan dalam format file ".cs".

4. Implementasi Layar Antarmuka Perangkat Lunak a. Antarmuka Menu Utama

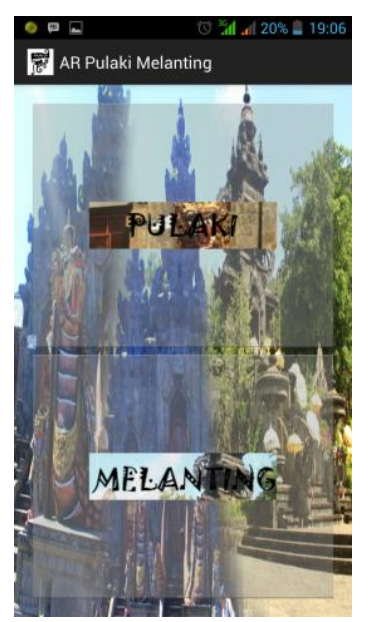

b. Antarmuka Splash Image

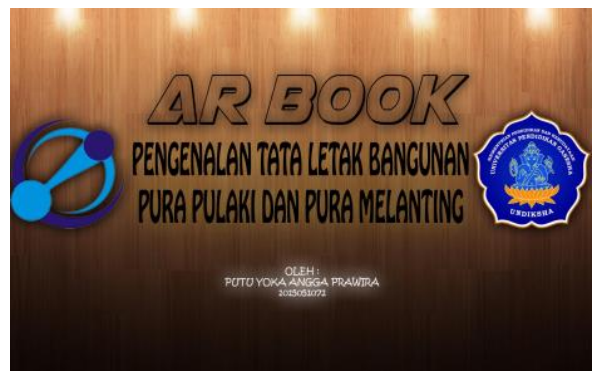

c. Antarmuka Petirtan

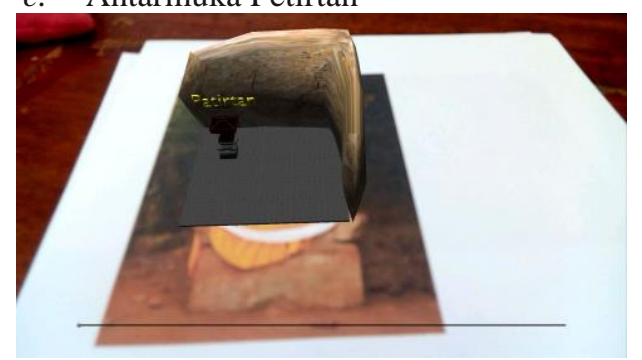

d. Antarmuka Pegaluhan

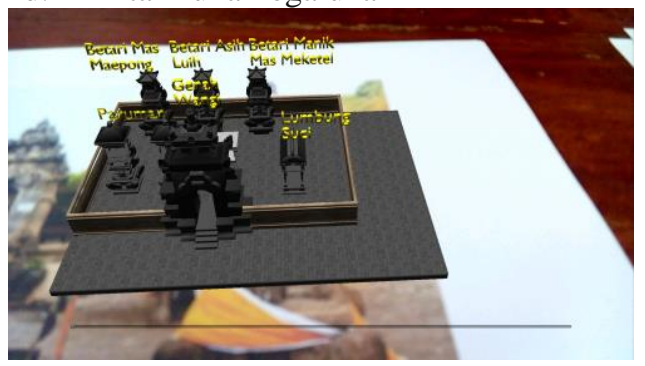




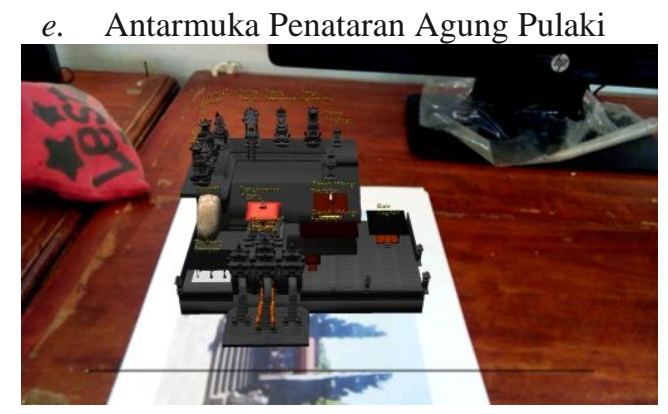

f. Antarmuka Jaba Tengah Pulaki

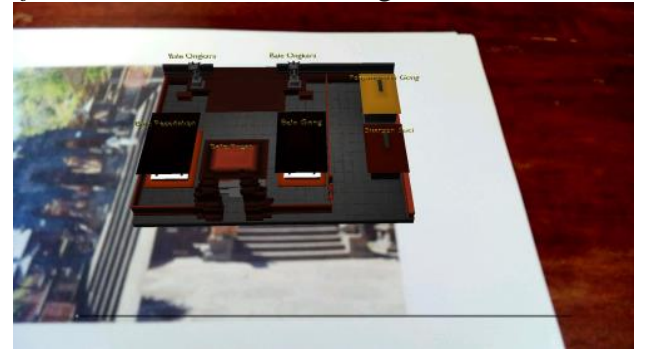

g. Antarmuka Jaba Sisi Pulaki

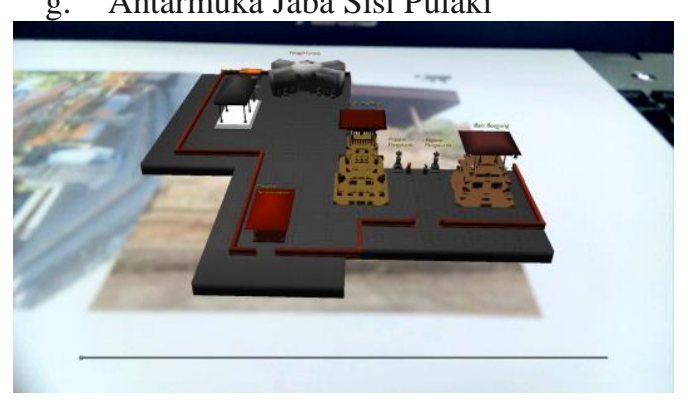

h. Antarmuka Jabaan Pulaki

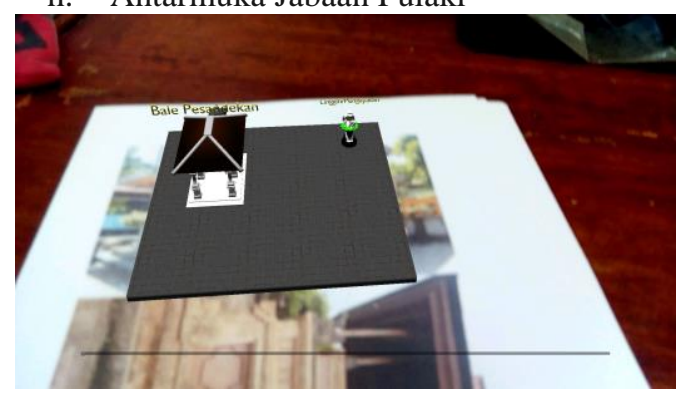

i. Antarmuka Penataran Agung Melanting
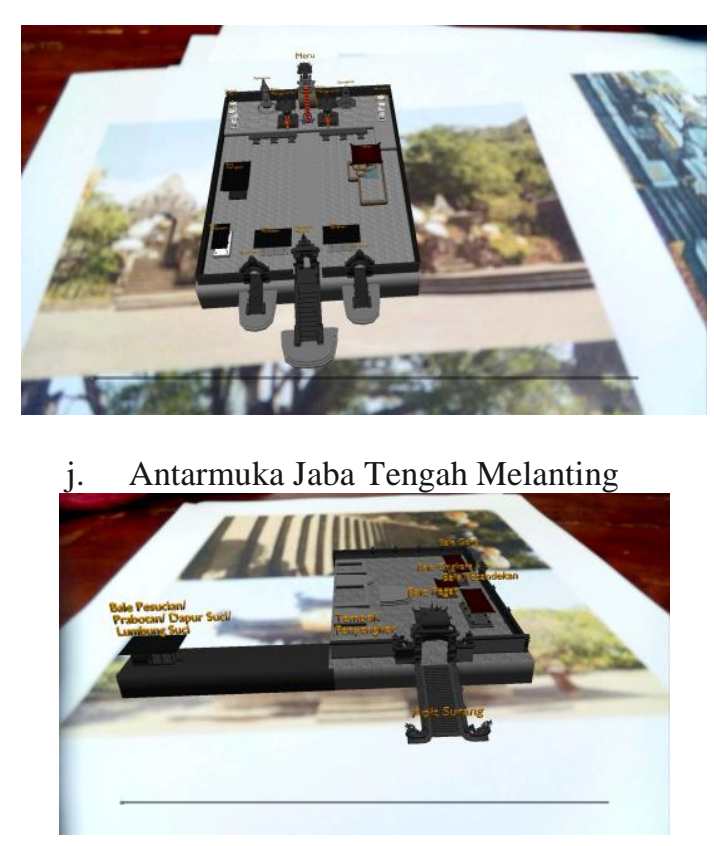

k. Antarmuka Kalangan Pasar Agung Melanting

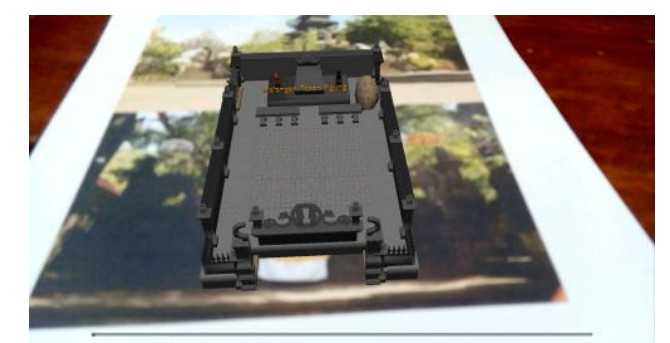

1. Antarmuka Jaba Sisi Melanting

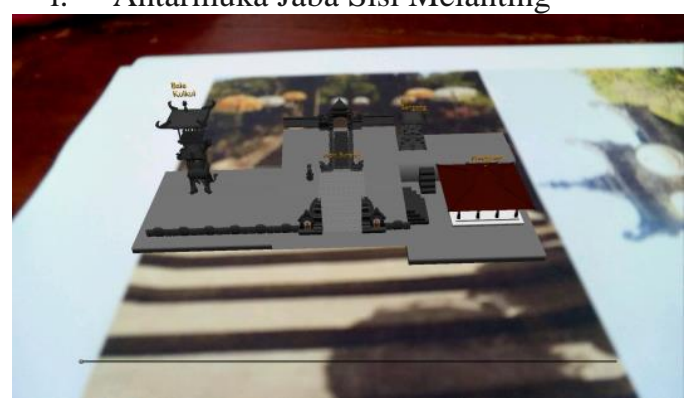

B. Pengujian Perangkat Lunak

Pengujian perangkat lunak merupakan proses menjalankan dan mengevaluasi sebuah perangkat lunak untuk menguji apakah perangkat lunak sudah memenuhi persyaratan atau belum untuk menentukan perbedaan antara hasil yang diharapkan dengan hasil sebenarnya.

1. Tujuan Pengujian Perangkat Lunak 


\section{ISSN 2087-2658 \\ Jurnal Nasional Pendidikan Teknik Informatika (JANAPATI) \\ Volume 4, Nomor 2, Juli 2015}

Pengujian perangkat lunak aplikasi Augmented Reality Book pengenalan tata letak bangunan Pura Pulaki dan Pura Melanting dilakukan dengan mempergunakan pengujian blackbox testing. Dimana pengujian ini hanya dilihat berdasarkan keluaran yang dihasilkan dari data atau kondisi masukan yang diberikan untuk fungsi yang terdapat pada perangkat lunak tanpa melihat bagaimana proses untuk mendapatkan keluaran.

1. Menguji kebenaran proses aplikasi Augmented Reality Book.

2. Menguji lama waktu menampilkan objek 3D.

3. Menguji penggunaan aplikasi Augmented Reality Book pengenalan tata letak bangunan Pura Pulaki dan Pura Melanting pada tiga orang dengan menggunakan smartphone android yang berbeda.

2. Pelaksanaan Pengujian Perangkat Lunak

Berdasarkan perancangan pengujian perangkat lunak di atas, maka pengujian aplikasi Augmented Reality Book Pengenalan Tata Letak Bangunan Beserta Landscape Alam Pura Luhur Batukaru dilakukan oleh: 1) Pengembang untuk pengujian kesesuai proses aplikasi; 2) beberapa orang mahasiswa dari jurusan Pendidikan Teknik Informatika, Universitas Pendidikan Ganesha Singaraja. Pengujian dilakukan sesuai dengan kasus uji yang telah dirancang sebelumnya dengan menggunakan tiga jenis angket yaitu:

- Angket Kesesuaian Proses Aplikasi

- Angket lama waktu menampilkan objek $3 \mathrm{D}$ di dalam ruangan

- Angket lama waktu menampilkan objek 3D di luar ruangan

- Angket penggunaan aplikasi pada jenis hardware berbeda

3. Evaluasi Hasil Pengujian

Melalui hasil pengujian angket kesesuaian jalannya proses aplikasi dengan marker pada buku, maka diketahui bahwa proses aplikasi telah sesuai dengan AR-Book Pura Pulaki dan Pura Melanting. Semua proses aplikasi dapat berfungsi dengan baik. Suara dan objek 3 dimensi yang ditampilkan sesuai dengan marker pada buku, selain itu fitur rotation untuk merotasi objek mampu berfungsi dengan baik.

Pada hasil pengujian melalui angket lama waktu untuk menampilkan (render) objek 3 dimensi pada siang dan malam hari, adalah dimana kedua kondisi memiliki waktu tercepat menampilkan objek 3 dimensi yaitu pada saat jarak smartphone ke penanda adalah $30 \mathrm{~cm}$. Hal ini disebabkan karena ketika berjarak $10 \mathrm{~cm}$ dan $20 \mathrm{~cm}$, masih ada gambar penanda yang sulit terdeteksi oleh kamerasecara keseluruhan.

\section{SIMPULAN}

Berdasarkan hasil analisis, implementasi dan pengujian pada penelitian pengembangan aplikasi Augmented Reality Book tata letak bangunan Pura Pulaki dan Pura Melanting, dapat ditarik kesimpulan sebagai berikut.

1. Aplikasi Augmented Reality Book pengenalan tata letak bangunan Pura Pulaki dan Pura Melanting dirancang menggunakan Flowchart Diagram dan Use Case Diagram dengan entitas pengguna (user).

2. Aplikasi Augmented Reality Book pengenalan tata letak bangunan Pura Pulaki dan Pura Melanting diimplementasikan dengan library Vuforia menggunakan aplikasi Unity 3D yang dapat melakukan pelacakan penanda sehingga mampu menampilkan objek 3 dimensi bangunan Pura Pulaki dan Pura Melanting beserta tata letaknya serta diikuti dengan suara narasi penjelasannya

3. Berdasarkan hasil pengujian mengindikasikan bahwa aplikasi Augmented Reality Book pengenalan tata letak bangunan Pura Pulaki dan Pura Melanting, dapat digunakan sebagai sarana guna menarik minat pembaca untuk mempelajari, memperkenalkan dan melestarikan Pura Pulaki dan Pura Melanting.

\section{REFERENSI}

[1] Geriya,I W. 2008. "Transformasi Kebudayaan Bali Memasuki Abad XXI". Surabaya: PARAMITA.

[2] Gelebet, N. 1982."Arsitektur Tradisional Daerah Bali”. Jakarta: Departemen Pendidikan dan Kebudayaan.

[3] Wiartika, I M. E., Crisnapati, P N., \& Darmawiguna I G. M. 2013. Augmented reality book sistem rumah tradisional bali berdasarkan asta kosala-kosali. Jurnal Nasional Pendidikan Teknik Informatika. Volume 2(3). 234-242. http://pti.undiksha.ac.id/janapati/vol2no3/6.pdf. Diakses tanggal 17 Februari 2014.

[4] Monica, W, S., Widyastuti, S, K., \& Wandia, I N. 2007. Keragaman genetik populasi monyet ekor panjang di Pura Pulaki menggunakan marka molekul mikrosatelit D13s765. Indonesia Medicus Veterinus. Volume 1(1). 37-54. http://ojs.unud.ac.id/index.php/imv/article/down load/641/467. Diakses tanggal 22 Januari 2014.

[5] Suyanto, M., 2003, Multimedia Alat untuk Meningkatkan Keunggulan Bersaing, Andi Offset, Yogyakarta. 